\title{
Indole, a Privileged Structural Core Motif
}

\section{Isaac Giménez Sonsona}

Laboratorio de Organocatálisis Asimétrica, Departamento de Química Orgánica, Instituto de Síntesis Química y Catálisis Homogénea (ISQCH), CSIC-Universidad de Zaragoza, Cl Pedro Cerbuna 12, E-50009 Zaragoza, Spain

sonsona@unizar.es

Published online: 14.08 .2015

DOI: 10.1055/s-0034-1381172; Art ID: st-2015-v0526-v

\section{Introduction}

Indole (1), denominated by some authors as The Lord of the Rings of heterocyclic compounds ${ }^{1}$ due to its importance in fields like chemistry, biology, and medicine, ${ }^{2}$ represents the structural core of many natural and non-natural products with a wide range of biological properties, including antiviral ${ }^{3}$ and anticancer ${ }^{4}$ activities. An example of this spectrum of utilities is Arbidol (2), which is administered as a drug in Russia and China against influenza and other respiratory viral infections. ${ }^{5}$ Recent examples of other applications of indole-containing compounds are their potential use in SPECT imaging or detecting $A B$ plaques in Alzheimer's disease, as compound $3,{ }^{6}$ or their use as ligands in the synthesis of organometallic complexes with optoelectronic properties and with potential use in the construction of light-emitting devices. ${ }^{7}$<smiles>c1ccc2[nH]ccc2c1</smiles><smiles>CCOC(=O)c1c(CSc2ccccc2)n(C)c2cc(Br)c(O)c(CN(C)C)c12</smiles>

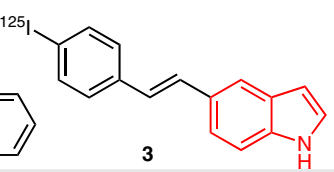

Isaac Giménez Sonsona was born in Zaragoza, Spain, in 1991. He received his B.S. in chemistry at the University of Zaragoza in 2014. He is currently working towards his $\mathrm{PhD}$ degree in the Department of Organic Chemistry at the University of Zaragoza under the supervision of Dr. Raquel P. Herrera and Dr. Eugenia MarquésLópez. His primary research interest focusses on the enantioselective organocatalytic study of different organic reactions aimed at the asymmetric synthesis of potential biologically active compounds.

\section{Preparation}

The interest in the synthesis of indole rings from the last century to the present day is due to the important biological activities that compounds with this privileged structural core exhibit. Therefore, many different synthetic approaches have been developed in order to obtain these scaffolds. ${ }^{8}$ Undoubtedly, the most important method to obtain differently substituted indoles is the Fischer synthesis. ${ }^{9}$ In this crucial reaction, arylhydrazines 4 react with ketones or aldehydes $\mathbf{5}$ by heating in the presence of an acid to give the corresponding functionalized indoles $\mathbf{6}$ with good yield (Scheme 1).

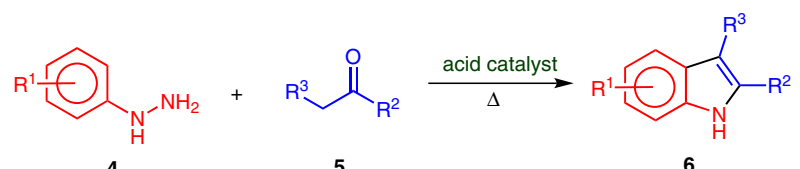

Scheme 1 Fischer synthesis of indole derivatives

Figure 1 Indole-based target compounds

Table 1 Use of Indole, a Privileged Structural Core Motif

\section{(A) N1 Reactivity:}

The total synthesis of the monoterpene alkaloid mersicarpine (10) was reported in 2014 by Liang's group. ${ }^{10}$ The synthesis involves the nucleophilic attack of the $\mathrm{NH}$ of the indole $\mathbf{7}$ to the activated carboxylic acid $\mathbf{8}$, giving the corresponding amide intermediate $\mathbf{9}$. This allows access to indole analogue 10, an unusual seven- membered cyclic imine fused with a $\delta$-lactam with two stereogenic centers.

\section{(B) C2 Activation:}

Zhang and co-workers ${ }^{11}$ reported the synthesis of $\mathrm{N}$-(6-(indol-2yl)pyridine-3-sulfonamide 13 starting from the substituted indole 11. The mechanism involves the boronic acid intermediate $\mathbf{1 2}$.
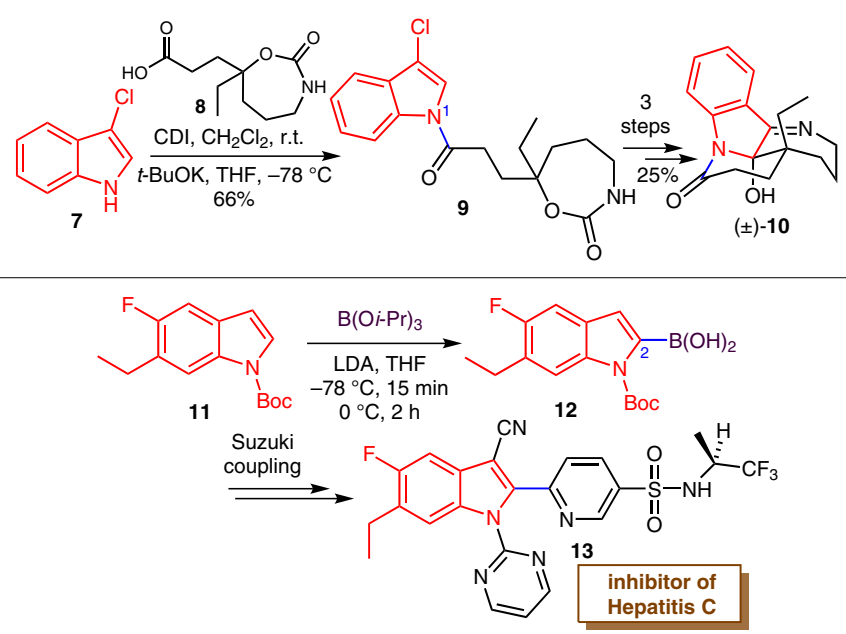
(C) C3 Reactivity:

In 2014, McLaughlin's group ${ }^{12}$ published the synthesis of the violacein scaffold 17, a microbial pigment with antimicrobial and anticancer activities. Indole derivatives $\mathbf{1 4}$ react at the $\mathrm{C} 3$ position with the acyl chloride derivative $\mathbf{1 5}$ to afford the main product 16, key in the construction of violacein analogues 17.

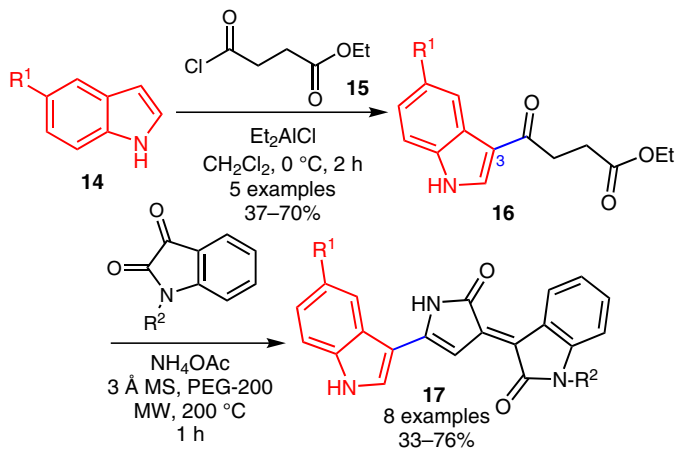

(D) C4 Activation:

Lanke and Prabhu reportedthe direct functionalization of $\mathrm{N}$-protected indole-3-carbaldehyde derivatives $\mathbf{1 8}$ at the C4 position under mild conditions employing ruthenium as a catalyst and with the aldehyde functionality as the directing group. ${ }^{13}$ This reaction could be crucial in the synthesis of organic targets such as ergot- and related alkaloids.

(E) C5 Activation:

In 2013, Liebhold and Li reported the benzylation of tryptophan derivatives 19 at the $C 5$ position of the indole ring using the fungal dimethylallyl transferase FgaPT2 (20).${ }^{14}$ This method gives access to pharmacologically active lipophilic chain containing compounds $\mathbf{2 1}$ in moderate yield.
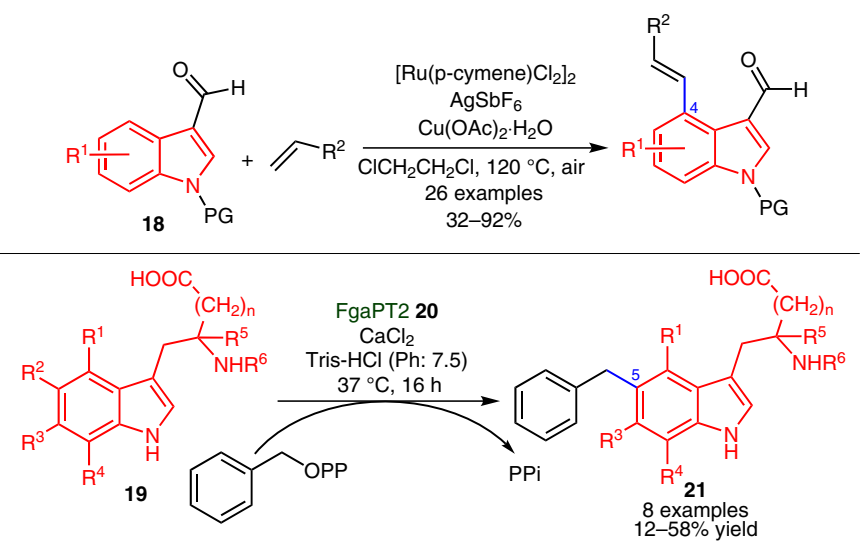

(F) C6 Reactivity:

In 2014, Shi and co-workers developed a Brønsted acid organocatalyzed arylation of 3-indolylmethanol derivatives $\mathbf{2 2}$, affording a direct method for $\mathrm{C} 6$ functionalization of substituted indoles $\mathbf{2 3}$, leading to scaffolds $\mathbf{2 4 .}{ }^{15}$

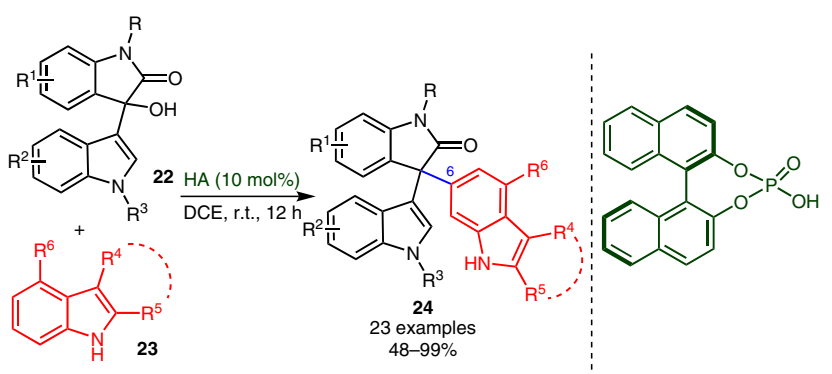

\section{References}

(1) Bandini, M.; Eichholzer, A. Angew. Chem. Int. Ed. 2009, 48, 9608.

(2) Kaushik, N. K.; Kaushik, N.; Attri, P.; Kumar, N.; Kim, C. H.; Verma, A. K.; Choi, E. H. Molecules 2013, 18, 6620.

(3) Zhang, M.-Z.; Chen, Q.; Yang, G.-F. Eur. J. Med. Chem. 2015, 89, 421.

(4) (a) Singla, R.; Singh, V.; Negi, A. Adv. J. Pharm. Life sci. Res. 2013, 1, 7. (b) Kumar, N. M.; Kumar, D. Chem. Biol. 2013, 3, 276.

(5) Blaising, J.; Polyak, S. J.; Pécheur, E.-I. Antiviral Res. 2014, 107, 84.

(6) (a) Yang, Y.; Jia, H.-M.; Liu, B.-L. Molecules 2012, 17, 4252. (b) Yang, Y.; Cui, M. Eur. J. Med. Chem. 2014, 87, 703.

(7) Yu, J.; Luo, J.; Chen, Q.; He, K.; Meng, F.; Deng, X.; Wang, Y.; Tan, H.; Jiang, H.; Zhu, W. Tetrahedron 2014, 70, 1246.

(8) Taber, D. F.; Tirunahari, P. K. Tetrahedron 2011, 67, 7195.
(9) (a) Fischer, E.; Jourdan, F. Ber. Dtsch. Chem. Ges. 1883, 16, 2241. (b) Strategic Applications of Named Reactions in Organic Synthesis; Kürti, L.; Czakó, B., Eds.; Elsevier Academic Press: Amsterdam, 2005.

(10) Lv, Z.; Li, Z.; Liang, G. Org. Lett. 2014, 16, 1653.

(11) Zhang, N.; Zhang, X.; Zhu, J.; Turpoff, A.; Chen, G.; Morrill, C.; Huang, S.; Lennox, W.; Kakarla, R.; Liu, R.; Li, C.; Ren, H.; Almstead, N.; Venkatraman, S.; Njoroge, F. G.; Gu, Z.; Clausen, V.; Graci, J.; Jung, S. P.; Zheng, Y.; Colacino, J. M.; Lahser, F.; Sheedy, J.; Mollin, A.; Weetall, M.; Nomeir, A.; Karp, G. M. J. Med. Chem. 2014, 57, 2121.

(12) McLaughlin, E. C.; Norman, M. W.; Ko, T. K.; Stolt, I. Tetrahedron Lett. 2014, 55, 2609.

(13) Lanke, V.; Prabhu, K. R. Org. Lett. 2013, 15, 6262.

(14) Liebhold, M.; Li, S.-M. Org. Lett. 2013, 15, 5834.

(15) Zhou, L.-J.; Zhang, Y.-C.; Zhao, J.-J.; Shi, F.; Tu, S.-J. J. Org. Chem. 2014, 79, 10390. 